\title{
Luke 16:19-31: Intermediate State of the Soul
}

\author{
Daniel Berchie, Samson Dakio \\ Valley View University
}

\begin{abstract}
This study seeks to determine the meaning of Luke 16:19-31. The question of whether this passage teaches intermediate state of the disembodied soul after death has been a theological conundrum. In Lucan context, both thematic and linguistic considerations suggest that the passage can be a pre-resurrection tradition. Having studied the setting in which Jesus tells this parable and Lucan context, this study, employing a quasi-allegorical method, concludes that the presentation of the unseen world represents events and class of people in the eschatological judgment.
\end{abstract}

Keywords: intermediate, soul (spirit), quasi-allegorical, eschatological judgment, Lazarus, rich man

\section{Introduction}

In Luke 16:19-31, a life and afterlife story (Plummer 1977, 390-1; Borland 1978, 158) is told about a certain rich man and a poor man called Lazarus. This story has spawned a considerable discussion among biblical scholars, commentators, and systematic theologians. The discussion concerns the literary integrity and theology of the story. Of the latter, some have taught that the belief in an intermediate state of the soul finds its confirmation in this passage, hence, biblical. The consciousness of Abraham, Lazarus, and the rich man in afterlife, as it is argued, betrays the dualistic view of human nature (body-soul equation) that the disembodied or immaterial aspect lives on after death (Erickson 1998, 545, 554-7; Grudem 1994, 821-2; Womack 1995, 248-51; Marshall 1978, 636; Jeremias 1964-1976, Vol. 5, 769; TDNT, Vol. 1, 146-9; Borland, 158; Reiling and Swellengrebel 1971, 571-2; Kendall 2004, 286-7; Morris 1986, 252). Based on this passage, Wayne Grudem can confidently say that the OT believers, upon their death, "entered immediately into heaven and enjoyed a time of fellowship with God" (Grudem, 822). He insists that the unbelievers enter into "a state of eternal punishment immediately upon death" and "their bodies will be raised and united with their souls" (Grudem, 824). With reference to unbelievers' punishment, Joachim Jeremias argues that the use of hades instead of geenna indicates a provisional state of the punishment of the wicked, particularly in this story (Jeremias, Vol. 5, 769; Vol. 1, 146-9; Cf. Drury 1985, 149-50; Morris, 253; Stein 1992, Vol. 24, 424). On the other hand, other scholars believe that the passage does not demonstrate an intermediate state of the soul (Black 1996, 282; Nichol, 830-5; Blomberg 1990, 203-8; Evans 1990, 249; Geldenhugs 1983, 427-9; Plummer, 390-8; Liefeld 1984, 990-2; Wright 2002, 80; Hultgren 2000, 113-6). A picture of realized eschatology is painted with this story of afterlife to describe the final destination of both the righteous and the wicked, but not necessarily an intermediate state of the disembodied (Hultgren, 113; Cf. Marshall, 637). It is so argued that squeezing more

Daniel Berchie, Ph.D., School of Theology and Missions, Valley View University, Ghana; main research field: Biblical Studies (NT emphasis). Email: sperger123@yahoo.com.

Samson Dakio, MABTS candidate, School of Theology and Missions, Valley View University, Ghana; main research field: Biblical Studies (OT emphasis). Email: dakiosamson@yahoo.fr. 
out of this story is unnecessary and unscriptural (Blomberg, 207; SDABC, Vol. 5, 830-1; Geldenhugs, 429).

The literary integrity of the story is much debated as well. The debate has centered on whether this story can be attributed to Jesus. Some hold that the story, in its entirety, can be attributed to Jesus (Bauckham 1991, 45; Marshall, 634; Blomberg, 203-5; Jeremias 1972, 186; Fitzmyer 1985, 1127; Hock, Vol. 4, 266-7) while others consider it as a pre-Christian tale attributed to Jesus (Bultmann 1963, 203), later Apocryphal interpolation (the entire story, Cairus 2006, 35-45) or Lucan redaction (Drury, 159-60). Following Adolf Jülicher, some scholars have seen two literary units: part one (16:19-26) and part two (16:27-31, Jülicher 1910, Vol. 2, 634). While they consider the first part as pre-resurrection, they take the second as post-resurrection addition by the early Christian (Oesterley 1936, 209-11; Nolland 1993, 826). A beacon of the hermeneutics of this pericope in Luke is its genre. It has been variously argued that the story is a parable teaching moral truth (Blomberg, 203-6; Black, 282; SDABC, Vol. 5, 830-1; Plummer, 390; Stein, 422) or reflecting eventual happenings in the afterlife (Womack, 248), or real historical event (Borland, 158; Plummer, 390-1). These and other related issues have some bearing on the understanding of the story. The purpose of this study is to determine whether this story (1) can be attributed to Jesus or not in its present form; (2) is a parable or real historical event; and (3) teaches intermediate state of the disembodied soul after death. To this end, an exegetical approach is employed to tackle these and other related issues. The study is presented in three parts: (1) literary Integrity, (2) Genre and hermeneutical scheme, and (3) contextual analysis (quasi-allegorical analysis) of Luke 16:19-31.

\section{Literary Integrity of Luke 16:19-31}

This section seeks to address the question of integrity and unity of this passage. It is relatively free of issues of textual criticism. $\hat{1}^{75}$ (Bodmer, XIV) is the earliest manuscript from the third century which contains this story. External evidence for establishing the authenticity of the passage has been quite admirable (Cairus, 36). However, scholarly opinion has divided on the question whether this story can be attributed to Jesus in its present form. This hinges on internal evidence that either establishes or questions the literary integrity and unity of the passage. To address this, two considerations are brought to the fore: (1) thematic and (2) linguistic links.

\subsection{Thematic Link}

According to chapter divisions of Luke, the story of the rich man and Lazarus falls under chapter 16 . This chapter has generally been considered as belonging to the Travel Narrative (9:51-19-27, Hultgren, 111; Nolland, 825) and conclusion on the Lucan subject on the use and abuse of riches (Nolland, 825; Evans, 298). In this chapter, Jesus first tells his disciples a story about a certain rich man and steward (v. 1). The disciples are the main immediate audience. It is noteworthy that at the close of the story, v. 14 states that the Pharisees "also" (de, Wallace 1996, 671) heard this story and they sneered at him because they were covetous. This suggests that the Pharisees were present and can also be seen as audience. With the sneering in v. 14, Jesus directly addresses the Pharisees (autois, Wallace 171-3) from v. 15 without interrupting it with another audience until 17:1, where he addresses the disciples. Chaper 16:15-31 constitutes Jesus' response to the Pharisees' sneering in v. 14.

The story seems abrupt in its present place (Reiling and Swellengrebel, 569-70). Aecio Cairus argues for, while excluding 16:19-31, a smooth transition from 16:18 to 17:1 (Cairus, 43). He sees vv. 19-31 as an interruption of the flow and that 17:1-2 belongs "to the same condemnation of Pharisaic doctrine introduced in 16:15-17" (Marshall, 632). Such division seems synthetic at its best. With the response of the disciples in 17:5 
to his sayings from vv. $1 \mathrm{~b}$ to 4 , the disciples are the audience, but not the Pharisees (v. 1a) (Hultgren, 111; Cf. Marshall, 632; Cairus, 43). This suggests that $16: 15-31$ is a response to the covetous Pharisees who sneered at Jesus. That v. 19 is set off by "there was a certain rich man..." makes vv. 19-31 apparently a literary unit found within vv. 15-31. The covetous Pharisees are not the addresses or concerned addresses in 17:1, 5. Arland Hultgren notices that the story is related to the preceding statement on wealth $(16: 9,11,13,14-15$, Hultgren, 111). It seems reasonable to say that vv. 19-31 falls within vv. 15-31, Jesus' response to the covetous Pharisees (v. 14, Cf. Cairus, 43), while 17:1ff is addressed to the disciples.

The story unfolds that the rich man sumptuously lives everyday while at his gate laid a poor man with sores (v. 19-21). Two of them died. While the rich man was buried, Lazarus was carried by the angel to Abraham's bosom. While the rich man was tormented in Hades, Lazarus was at peace in Abraham's bosom (vv. 22-23). He pleaded with Abraham to send Lazarus to dip the tip of his finger to cool his tongue (v. 24). However, Abraham told him that while he had good times in his life and Lazarus suffered, he was in agony in Hades, and Lazarus was being comforted in his bosom (v. 25). Besides, a great chasm had been fixed between them and the rich man, adds Abraham (v. 26). The rich pleaded with him again to send Lazarus to warn his brothers so that they would not come to Hades (vv. 27-28). Abraham said that they had Moses and the prophets to listen to (v. 29). The rich insisted that perhaps a warning from a risen dead person would convince them (v. 30), but Abraham maintained that Moses and the prophets were enough (v. 31). Several repeated points are noted in this story, namely, (1) wealth (rich) and poverty (needy), (2) reversal of fortunes, and (3) obedience to Moses (law) and the Prophets.

\subsubsection{Wealth and Poverty/Reversal of Fortunes in Luke}

The theme of wealth and poverty/reversal of fortunes is obvious in Luke. Jesus looks at his disciples and pronounces blessings on the poor, hungry, mourners, and the persecuted, assuring them of their heavenly reward (6:20-23). However, he declares woe against the rich because they have already received their comfort and have already been satisfied (v. 24; Cf. 16:25). In an attempt to warn his disciples against greediness, Jesus tells a parable of the rich fool. The rich man stores grains and goods for himself for many years. He intends to enjoy life with his possessions. God, however, calls him a fool and takes his life from him that night. Therefore, Jesus says that the life of human being does not consist in the abundance of possessions (12:1, 13-21). Jesus enjoins his followers to sell their possessions and give to the poor. By doing so, they lay up treasurers in heaven (vv. 32-34). The rich are urged to invite the poor to their banquets for the rich who will be repaid at the resurrection of the righteous (14:14). Chapter 16 presents this theme in two ways. First, a story is told of a certain rich man and a dishonest steward. The steward makes the debtors pay less the amount owed so as to secure for him some comfort in the future. In the final analysis, the rich man commends the steward for being wise in his dealings (vv. 1-8). Jesus, then, urges, "use worldly wealth to gain friends for yourselves, so that when it is gone, you will be welcomed into eternal dwellings" (v. 9). This suggests using wealth to care for the poor, that is, gaining friends for oneself, amounts to investing in heaven. Thus, when one dies, one will be welcomed by the beneficiaries. Since Luke equates poverty and piety, the beneficiaries are the poor.

Among the synoptic Gospels (Matt. 6:1-4 regulates the acts of giving to the poor), only Luke betrays much interest in this topic of wealth and poverty/reversal of fortunes. He demonstrates Jesus' attitude towards the rich and concern for the poor (Davids 1992, 704-5). Jesus pointedly tells a certain ruler, who wants to know what to do to inherit eternal life, to sell all that he has and follows him. When he refuses, Jesus says that it is difficult for the rich to enter the kingdom of God (18:18-25; Cf. Matt. 19:16-24; Mark 10:17-23). Again, the narrative of 
Zacchaeus is emphatic in Luke's interest in the poor. According to the narrative, after Zacchaeus, a wealthy man (Luke 19:2) has given half of his possessions to the poor; Jesus says, "Today salvation has come to this house, because this man, too, is a son of Abraham." It is only in Luke that the story of Zacchaeus is found immediately after the ruler's quest for salvation in 18:18-25. When Zacchaeus does what the ruler could not do, he receives salvation in that same day and earns himself reward in heaven (Cf. 6:20-23; 12:16-21). In sum, Jesus' attitude towards the rich and their salvation is more pronounced in Luke, an uncompromising theme. The poor are the less privileged on earth but are more favored in the kingdom of heaven than the rich, except when they care for the poor while on earth.

\subsubsection{Moses/the Law and the Prophets in Luke}

Usually, Luke 16:19-31 is divided into two parts (2). The second part (vv. 27-31) is considered redactional or post-resurrection composition of the early church. Verses 15-31 constitute a unit in which vv. 19-31 fall. The teachings of Moses (sometimes the law, 24:27; 44) and the prophets appear throughout the unit (vv. 16, 17, 18, 29, 31), signifying a thematic unity. The Seventh-day Adventist Commentary's observation is apt: "In vv. 17, 18 Jesus affirms that the principles set forth in 'the law' are immutable - God has not changed - and give an example of this sublime truth. The parable of the Rich Man and Lazarus is then given to show that destiny is decided in this present life by the use of its privileges and opportunities" (SDABC, Vol. 5, 830; Black, 281). Craig Blomberg sees the division of the passage into two parts as artificial. He sees a clearer break after v. 23, where the dialogue begins, than between vv. 26 and 27 (Blomberg, 204). He sees a verbal repetition of an address in vv. 24, 27 ("father," have mercy on me," "I beg you"). Like Craig Evans (Evans, 249), Blomberg identifies "the theme of "too late"" (Blomberg, 204) in the passage. "The rich man pays attention to Lazarus too late; he sees the unbridgeable chasm too late; he worries about his brothers too late; and he heeds the law and the prophets too late" (Blomberg, 204). The pericope is not about resurrection, as Cairus notes (Cairus, 38). He is right when he says that the Pharisees "never questioned the concept of an afterlife as the Sadducees did" (Blomberg, 204). Therefore, a theme of resurrection may not be in view. Rather, Moses and the prophets are enough for the rich to know and practice the way of the Lord with regards to caring for the poor. This suggests that the pericope is thematically intact and can be traced back to Jesus (Evans, 249-50; Liefeld, 991). That the passage's theme of wealth and poverty/reversal of fortunes cohere with Jesus' attitude toward the rich and concern for the poor in Luke may be underlined.

\subsection{Linguistic Links}

Linguistic features inform the integrity and unity of the pericope. In the Greek, anthrōpos tis, "a certain man," in 16:19 appears Lucan in style (10:30; 16:1, this one agrees more with v. 19). Luke describes the rich man as euphrainomenos kath'ēmeran lamprōs, "rejoicing sumptuously daily" (v. 19). The word euphrainō occurs fourteen times in the NT, out of which eight occur in Lucan text (Carson, Moo, and Morris 1992, 185-201; Luke 12:19; 15:23f, 29, 32; 16:19; Acts 2:26; 7:41; Rom. 15:10; 2 Cor. 2:2; Gal. 4:27; Rev. 11:10; $12: 12 ; 18: 20$ ). This betrays a Lucan hand (Nolland, 828). Ptōchos de tis in v. 20 seems to parallel anthrōpos de tis in v. 20 in terms of structure. Again, ptōchos seems to be a technical word in Luke used to depict the less privileged on earth but more favored in the kingdom of heaven (Davids, 704-7; Hultgren, 112). The use of epithymōn chortasthēnai, "desiring to be fed," in v. 21 also parallels epethymei chortasthēnai in 15:16 (Nolland, 828). In particular, chortazo is used in Lucan contexts where the need to satisfy the hungry with food is in view $(6: 21 ; 9: 17 ; 15: 16 ; 16: 21)$. The fact that the poor is laid at the gate of the rich man suggests his desire to be fed 
with the crumbs from the rich man's table is intended (Black, 282; Hultgren, 112). In this case, the poor is depicted as a hungry person who needs to be satisfied with food, a Lucan theme. In short, epithymōn chortasthennai appears to be Lucan (Cf. Cairus, 39). In v. 22, another linguistic feature of Luke is egeneto de, "and it happened," plus infinitive $(1: 8 ; 2: 6 ; 3: 21 ; 5: 1 ; 6: 1,6,12 ; 9: 51 ; 11: 27 ; 18: 35$; Acts 4:5; 9:43; 14:1; 19:1; 28:17). The same style of the temporal clause eparas tous ophthalmous autou "when he lifted up his eyes" in v. 23 can be found in $6: 20$ (eparas tous ophthalmous autou). The phrase kai autos, "and he" (1:17, 22; 2:28; 3:23; $4: 15 ; 5: 1,14,17,37 ; 6: 20 ; 8: 1,22 ; 9: 51 ; 15: 14 ; 16: 24 ; 17: 11,16 ; 19: 2,9 ; 22: 41 ; 24: 15,25,28,31$; Acts 8:13; $21: 24 ; 22: 20 ; 24: 16 ; 25: 22 ; 22: 41 ; 24: 15,25,28,31$; Acts $8: 13 ; 21: 24 ; 22: 20 ; 24: 16 ; 25: 22$ ), and the word odynōmai (2:48; 16:24, 25; Acts 20:38) "I am in pain," in v. 24 seem Lucan. In v. 26, of significance is the expression en pas toutois, "besides all this," which also occurs in 24:21 (sun pasin toutois). The use of diamartyrētai, "he may testify," in v. 28 betrays Lucan hand (16:28; Acts 2:40; 8:25; 10:42; 18:5; 20:21, 23f; 23:11; 28:23). Although "the law and the prophets" is considered Jewish idiom (v. 16), Moysea kai tous prophetas, "Moses and the Prophets," in vv. 29,31 can be seen as Lucan reference to the idiom (24:27, 44; Acts 28:23; Cf. John 1:45). Lucan hand seems obvious in the use of the particle ouchi, "no," and the adversative conjunction all', "but," in v. 30 (12:51; 13:3, 5; 16:30; 17:8; Stein, 422).

In sum, with both thematic and linguistic considerations, the story of the rich man and Lazarus can be traced back to Jesus. The unity of the pericope seems original and pre-resurrection. With this presentation, the study turns to the question of the genre and hermeneutical scheme of the story.

\section{Genre and Hermeneutical Scheme of Luke 16:19-31}

The main objective of this section is to understand the genre (literary type) of the story of the rich man and Lazarus in Luke 16:19-31. This undertaking will, in turn, help determine an appropriate interpretive approach to understanding the passage in question.

Luke does not tell us the literary type of the story. As notable scholars and some early church fathers have noted, this story is unusual in that a character is named, Lazarus. In fact, this unusualness leads Ambrose and Tertullian $(5, \mathrm{n} .17)$ and some modern interpreters to see the story as "the true account of a real history of two people," to use James Borland's words (Borland, 158) or a created narrative based on Johannine account on the resurrection of Lazarus, the brother of Mary (Brown 1966, 428-30; Nolland, 827; Stein, 422 n. 221; Hultgren, 111). A closer look at some literary features may be helpful to assess the genre of the story. It is introduced as anthrōpos tis "a certain man" (v. 19). This formula is used to introduce many of Jesus' parables in Luke (Luke $10: 30 ; 14: 16 ; 15: 11 ; 16: 1 ; 19: 12$; Cf. 20:9). With this formula, these passages have been considered parabolic narratives (Stein, 422). The normal cliché of Jesus speaking a parable is introduced by indicating that it is a parable or by saying that the kingdom of God is like a person or thing (Luke 5:36; 6:39; 8:4, 9, 11; 12:16, 41; $13: 6 ; 14: 7 ; 15: 3 ; 18: 1,9 ; 19: 11 ; 20: 9,19 ; 21: 29$; Cf. Matt. 13:18, 24, 31, 33f, 36; 15:15; 21:33; 24:32; Mark $4: 13,30,34 ; 7: 17 ; 12: 12 ; 13: 28 ;$ John 10:6). However, it appears that this technique is not always used $(15: 8$, 11, 16:1). It can even be observed that while several OT narratives are labeled as parables (Num. 23:7, 18; 24:3, 15, 20f, 23; Isa. 14:4; Ezek. 17:2; 24:3; Mic. 2:4; Hab. 2:6.), several parables, though not labeled as such, are also construed as parabolic (Judg. 9:8-15; 2 Kgs 14:9). That the story of a certain rich man and Lazarus is a parable, as identified by many, seems plausible (SDABC, Vol. 5, 830-1; Blomberg, 205; Black, 282; Stein, 422).

If the story of the rich man and Lazarus is parable, why is it that the poor man is named, uncharacteristic of parables? Robert Stein notes that Jesus employs pun as he names the poor man Lazarus (Greek form of the 
Hebrew Eleazar, meaning "He whom God has helped"). This poor man can be identified with such poor people in 4:18; 6:20; 7:22; 21:3 (Stein, 423; Marshsall, 635; Nolland, 828; Geldenhugs, 428; Blomberg, 205-6). Howard Marshall perceptively observes that the poor are generally pious and recipients of God grace in Luke (Marshsall, 635). In a discourse framework, vv. 19-23 is narrative discourse while vv. 24-31 appears direct discourse. In the direct discourse, the rich needs Lazarus' help in cooling his tongue and/or warning his brothers to prevent them from coming to Hades. Although Lazarus is silent throughout the discourse, it appears the discourse revolves around him. It seems that the naming of the poor helps facilitate the dialogue between the rich man and Abraham. This may explain the unusual naming of a parabolic character (Blomberg, 203; Marshall, 635; Stein, 423). Granted, how should this parable be understood? Parable may be defined as an extended simile or metaphor (Tolar 2002, 27; Hauck, Vol. 5, 745, 752). In recent studies, parables are taught to express a point (Matt 20:1-16; Luke 11:1-4) or points of symbolic representations (Mark 4:1-20: Warren 2002, 327). Several Bible interpreters have been reluctant to employ allegorical approach in interpreting parables. However, if the literary context of the text allows it, it should be given its due force (Sloan and Newman 2002, 63; Warren, 327). Craig Blomberg understands that Jesus' parables betray some allegorical elements (Blomberg, 325). In short, the literary context of a parabolic text may determine their symbolic representations (Warren, 326).

A number of scholars have watered down an allegorical approach to understanding the parable of the rich man and Lazarus. Therefore, major points of the parable have been highlighted, ignoring some significant details (Plummer, 390-1; Geldenhugs, 428; Wright, 80; Black, 282). In fact, a description of the unseen world has created some discomfort and necessitated suppression of the details in the parable (Blomberg, 206-7; $S D A B C$, Vol. 5, 830-1; Geldenhugs, 428; Wright, 80; Black, 282; Plummer, 393). For example, Stephen Wright opines that "the aim of the story is not to give some sort of geographical information about the world afterlife" (Wright, 80). However, it seems fair to ask, if what goes on in the world matters, why should not that of afterlife matter? The cue to either look for major point(s) or press details has to be determined from the literary context.

In context, the covetous Pharisees are addressed by this parable (v. 14). They can be likened to the rich but foolish man (Cf. 12:16-22). Even though this parable may provide some major points as mentioned above, certain symbolic representations with their corresponding realities may be prized in Lucan context. For example, the parable of the prodigal son is narrated to address the murmuring of the Pharisees and the Scribes that the tax-collectors and the sinners, who draw near to Jesus, are also God's children (1:1,11-32). The central idea is that sinners are also God's children and if they so choose to repent and come to him, he is always willing to accept them back from their waywardness. Even though the central idea is obvious, there are some symbolic representations that give a complete thought of the story. For example, the ever-loving father, the first son, the younger son, far country, in context, may correspond to God, Pharisees and scribes, and the tax-collectors and sinners, waywardness respectively. Certain details such as his father's servants, swine, bread, robe, ring, shoes, fatted calf, field make the parable work without any corresponding realities (Stein, 424). This approach may be a quasi-allegorical interpretation of the parable in context. The parable of the rich and Lazarus has been considered as an example story for the covetous Pharisees (16:14; Nolland, 827; SDABC, Vol. 5, 830). It presents two scenes. The first represents this life (16:19-22) while the second is the afterlife (23-31). Blomberg keenly observes that there is more to the example story in that Abraham is the spokesperson of God, and that the rich man and Lazarus are representatives of certain characters in real life (Blomberg, 205). If the rich man 
and Lazarus represent certain characters in this life and Abraham as spokesperson of God in the afterlife, a quasi-allegorical approach can be employed to see the corresponding realities in and of the afterlife.

\section{Contextual Analysis of (Quasi-allegorical Analysis) Luke 16:19-31}

The contextual analysis of the passage concerns itself with the question of the afterlife of the rich and Lazarus and the intermediate state of their souls and consciousness. The analysis will be successful in consideration of the life setting of Jesus and the composition of the Gospel of Luke (Warren, 319). This study begins with the assumption that a human being is a composite of body and spirit (soul), following the OT's definition of human (Cf. Matt 10:28; Richards 1991, 575).

\subsection{Lazarus in Abraham's Bosom}

A certain rich man lived sumptuously while a poor man was laid at his gate. The poor desired to be fed at the gate (v.19-21). The poor man, named Lazarus, died and was carried by the angels to the bosom of Abraham while the rich man died and was buried. The rich man was in Hades (hadess), being in torment, while Lazarus was in Abraham's bosom (kolpos). With this afterlife scenario, Kendall believes "that hell is a place of conscious punishment, not annihilation" (Kendall, 287). Morris Womack reminds us, "Jesus never misrepresents facts in his parables" (Womack, 248). However, it is clear from the passage that Lazarus did not go to Hades (hadēs). Some details are left out of the story. Jesus does not say that Lazarus is buried as the rich man is. The high point stressed is that Lazarus is taken by angels to the bosom of Abraham. Does this suggest that the disembodied soul is taken by the angels or both the body and the soul? Similarly, is the soul of the rich tormented in Hades or both the body and soul?

The poor man's name, Lazarus, is the Greek for the Hebrew Eleazar ('el $\bar{a} z \bar{a} r$ ) "he (whom) God has helped" (Brown, with Driver and Briggs, 1952, s.v. 'el $\bar{a} z \bar{a} r$ ). In addition to what has already been said, the fact that the rich man is buried and the poor man receives angelic escort suggests the poor man as the recipient of God's grace (Marshall, 636). To say the least, the poor in Luke have their reward in heaven. A Targum on Canticles 4:12 indicates that the souls of the righteous are brought to paradise by angels. This idea is not found in rabbinic sources. The Greek kolpos literally means "bosom," "breast," or "chest" (Bauer 1979, s.v. kolpos). It occurs six times in the NT and metaphorically depicts close intimacy (Luke 6:38; 16:22f; John 1:18; 13:23; Acts 27:39; Hock 1987, 448-55).

Outside scriptures, God says to his angels after the death of Abraham: "Lead my friend Abraham into Paradise where the tabernacles of my righteous are and the dwellings of my saints, Isaac, Jacob, and Abraham en tō kolpō autou" (Jeremiah, paradeisos, TDNT, Vol. 5, 769 n. 37; Test. Abr. 20 A). Marshall's comment is right that even though Abraham is thought to be in paradise, his bosom does not equate paradise (Marshall, 637). Abraham is thought to receive the righteous martyrs (4 Macc. 13:17). That may be why a great rabbi can be said to be in Abraham's bosom, a euphemism for being dead (b. Qidd. 72a-b. b. Bera. 28b; Nolland, 829. Test. Abr. 13:1-16; 14:1-10). Generally, it can be stated that Abraham's bosom metaphorically meant the righteous' closeness to Abraham in Paradise after death (Apocalypse of Moses 40; $b$. Shab 152b). In this way, the righteous, together with Abraham and the patriarchs, are visualized in bodily terms.

In the Hebrew Bible (Hereafter referred to as HB), the dead are said to have been "lied with their fathers" (e.g., Gen. 15:15; 25:7-10; 47:30; Judg. 2:10; 1 Kgs. 14:31; 16:26; 2 Kgs 15:38; 16:20). The expression generally signifies death with no inkling as to the bliss of the departed. All the patriarchs are buried (Gen. 
25:7-10; 35:29; 49:31; 50:12-13). Both the righteous and unrighteous are buried (e.g., Num. 11:31-34; 20:1; Deut. 10:6; 34:5-6). An exception is the mention of Enoch and Elijah ruptured by God (Gen. 5:24; 2 Kgs. 2:11-12). According to the HB, Abraham is dead and buried. In the NT, Abraham is said to be the father of the Jews (e.g., Matt. 3:9; Luke 13:16; 19:19; John 8:39; Rom. 4:12). At the eschatological banquet, the faithful will dine with Abraham, Isaac, and Jacob in the kingdom of God (Matt. 8:11-12). Those present at the banquet comprise both Jews and non-Jews who express faith in Jesus. Ultimate salvation setting at the eschatological consummation is envisaged in this passage (Luke 13:25; Berchie, 2010, 61-65). This suggests that reunion with the patriarchs is at the eschaton, not intermediate period between this life and eschatology. Before a more forceful conclusion is deduced, the parabolic meaning of hadēs in 16:22ff should be considered.

\subsection{The Rich in Hades (hadēs)}

The rich man is being tormented in Hades (hadēs). The Greek hadès originally signified the god of the netherworld. As a concept, it can be traced back to the second millennium BCE. The Mesopotamian and Egyptian mythological and mortuary texts indicate the belief in the consciousness of the soul in the afterlife (Wilson 1969, 32-34; Speiser 1969, 107; Bauckman 1998, 97). Of interest is an Egyptian tale about a soul that retuned from Amente (hadess) to the earth. Si-Osiris, the reincarnated soul, recounts reversal of fortunes of the rich and the poor in Amente. In Amente, the rich suffer while the poor sit with the god of Amente (Bauckman, 98; Fitzmyer, 1127). The ritual of necromancy in the then world affirms this belief (Cf. 1 Sam. 28; Seneca Herc. Oct, 1863-1976; Ovid Met. 14.829-51). In the Greek world, apart from hadēs being identified with the god of the netherworld, it is frequently used for the place of the dead (Homer The Odyssey 3.410; LCL, 1:99; 10.175; LCL, 1:357). Hadēs is a place where souls can engage in conversation (Homer The Odyssey, 11.50-90; LCL, 1:389-93), judged by the gods (Homer The Odyssey, 11.565-70; LCL, 1:427), and tormented (Homer The Odyssey). Plato highlights the dichotomy of body and soul of human being (Plato Georgias 3:419). Plato states that the soul is immortal and that it is preexistent and continues to exist after escaping from the body at death (Ferguson 2003, 334-5). Being in hadēs, the souls are free from the desires of the body (Plato Cratylus 4:47). The wicked receive several punishments in hadēs (The Laws 2.9.870, trans. Bury, LCL, 11:256-57). For Plato, souls with divine virtue are moved through a holy road to a better sphere (The Laws 2.10.904; LCL, 11:367).

In the LXX, out of 72 references, hadēs occurs 61 times as translation of the Hebrew sheol, "grave," "underworld," "abode of the dead," "degradation of sin," and "symbol of place of exile" (BDB, s.v. sheol). With reference to the dead, generally sheol is the realm of both the righteous and the unrighteous dead in the OT (e.g., Gen. 37:35; Num. 16:30; BDB, s.v. sheol). sheol or hadēs appears to be the place of the dead not the soul (spirit). The OT is silent on the question of immortality of the soul (spirit) (Cf. Gen. 37:35). A picturesque scene of the afterlife is not attested to in the OT. The dead do not praise the Lord, rather it is the living that do (Ps. 6:5; 115:17; Isa. 38:18-19). The dead do not see oppression as the living do, so the dead are happier than the living (Prov. 4:1). It may suffice to say that sheol or hadēs refer to the grave where all the dead are buried. It depicts a place of gloom and despair, forgetfulness and where the presence of YHWH is withdrawn. If the preacher's understanding is correct, then the spirit (soul) returns to the giver, God, while the dust returns to the earth (12:17). That is why the preacher urges the living to enjoy life to the full $(2: 24 ; 3: 12 f, 22 ; 5: 180-20 ; 6: 3-6$; $8: 15 ; 9: 7-10 ; 11: 9 f ; 12: 1-8)$. This suggests that bodily emotions and activities may be restricted to body-soul equation on earth, not beneath the earth (Bar 1992, ch. 1). In short, sheol or hadēs in the OT is the place for both the righteous and unrighteous dead, and that death was not the escape route for the spirit (soul). 
In the Post-biblical Judaism, the place of hadēs in socio-religious setting is worth noting. To begin with, Sirach mimics the belief in the OT that both good and bad persons go to hadess (14:16-19; 17:25-32; 38:16-23; $41: 4 ; 48: 4-5 ; 51: 5-6)$. However, Psalms of Solomon indicate that hadēs is the place for punishing the wicked $(2: 23-3: 10 ; 5: 15 ; 8: 13,17 ; 15: 2-3)$. Fourth Maccabees indicates immortality of the soul as a reward for righteousness, not as quality of nature (18:23; Wisdom of Solomon 3:1-2; Pesudo-Phocylides, 105-15; Sybylline Oracles 4.179-92). 2 Esdr 7:75-140 describes the intermediate torment of the ungodly souls and the blessings of the godly souls between death and the final Day of Judgment (Ethiopic Enoch 22:1-15.). However, in some rabbinic sources, the judgment is passed at death (Sifre on Num. 13:8; Mekilta on Exod. 15:1; $b$. Sanh. 91a). Philo also teaches that the soul is immortal imprisoned in the body, reflecting platonic worldview (e.g., Philo Questions on Gen. 3:1; Leg. 1.33; 3.14. 42; Migr. 2.9; Spec. 1.295. 123; Opif. 1.145ff). The Pharisees, according to Josephus, both the souls of the righteous and the wicked receive their reward and punishment under the earth respectively (Jos. Ant. 18.14). Josephus shares this Platonism but rehearses the view that the souls of the faithful are in heaven while those of the wicked are held in the darkest place in Hades (hadēs; Jewish War 1.650; 2.163; 3.371-74; 7.3443-8; Apion. 2.217; Ant. 18.14). The same can be said of the Qumran community (4Q521). Targum Jonathan on 1 Sam. 25:29 says that the souls of the righteous are in the treasury while those of the wicked are in Gehenna (geenna) or any unpleasant area (Targum Jonathan on Isa. 27:12f). In some Jewish tradition, Gehenna is the place of punishment with fire (b. Hagigah 15a; Pesahim 54a). The duration of the punishment can either be eternal, temporary, or complete extermination (Midrash Rabbah on Gen. 26 on 6:3; Tos. Sanh. 13.3ff; 4 Esdr. 7:36). In the Post-biblical Judaism, it may be said that fluidity of the nature of the judgment of the wicked abounds.

Hadēs occurs ten times in the NT (Matt. 11:23; 16:18; Luke 10:15; 16:23; Acts 2:27, 31; Rev. 1:18; 6:8; 20:13f). Following Jeremias (Jeremias 1964-1976, 148-9), Norval Geldenhugs argues that there is no evidence in the NT that the faithful at their death go to the realm of the dead (hadess; Geldenhugs, 429; Morris, 253). However, it appears that a closer look at the use of hadess in Acts 2:27, 31 may, for example, indicate otherwise. In context, Peter appeals to Ps. 16:10 as Testimonia, testifying to the messiahship of Jesus (Ellis 2002, 74-75). Speaking of Jesus' resurrection, Peter sees a fulfilled prophecy in the Psalms (Acts 2:31) and probably uses the LXX version. The Psalmist's theme in ch. 16 is preservation of the Psalmist by YHWH. Peter quotes the poetic lines as they appear in the HB. In Acts 2:27 as in Ps. 16:10, the statement gives the reason why the Psalmist rejoices and his flesh shall dwell in hope (Acts 2:26; Cf. Ps 16:9). The first line of Acts 2:27 says that God will not abandon the soul (life) of the Psalmist in Hades (hadēs). The second indicates that God will not allow his holy one to see corruption. If Hades is the realm of the dead, then it is where the corruption of the flesh can take place. The structure of these poetic lines appears to be synonymous parallelism. This means that these lines "express the same idea with different but equal words" (Byargeon 2002, 281). Verse 31 confirms this understanding. The point here is that Jesus himself goes to the realm of the dead but is not left to corrupt. If the one that the faithful follow goes to the Hades, what prevents them to go there too at death (Aune 1998, Vol. 52B, 401-02; Stefanovic 2002, 97, 570)? To say the least, the righteous went to Hades in the NT.

One of the theological statements in the NT is the consummated eschatological judgment. Jesus declares that, at his coming with attendant glory, he will reward everyone according to their work (e.g., Matt. 16:27; 25:31-41; Cf. 5:12; 6:1-2; Luke 6:23). In Matt. 6:4, 6, 18, God repays good work. An account will be given on the Day of Judgment for every careless speech (12:36; 1 Pet. 4:5). The apostles believed and taught that the reward of the righteous is in heaven, and it will be given them during the day of judgment (Rom. 2:6; 1 Thess. 
4:16,17; 2 Tim. 4:1,8,14; Rev. 11:18; 22:12). In the clearest terms, Paul says that this mortal body will put on immortality during resurrection (1 Cor. 15:51-5). The statement in 2 Tim. 4:8 is apt: "Henceforth there is laid up for me the crown of righteousness, which the Lord, the righteous judge, shall give to me at that day; and not to me only, but also to all them that have loved his appearing" (ASV). The eschatological tone of these references suggests that the reward given to both the righteous and unrighteous will be on the Day of Judgment. It can further be pressed that they become conscious when receiving this reward at the resurrection period, not in the underworld.

\subsection{Wealth and Poverty in the Life Setting of Jesus}

The story of the rich and Lazarus is told as a parable so it must be understood as such. Wealth in Luke is considered evil if it is not used to care for the poor. Taking care of the poor secures one a place in heaven (18:18). In the Law and the Prophets, the rich has responsibility for the poor (Exod. 22:25; 23:11; Lev. 19:10; 23:22; 25:29; Deut. 15:7,9; Esth. 9:22; Isa. 3:14-15; 10:2; 41:17; 58:7). Wealth is considered as God's blessing and is not viewed as evil (10:22). Abraham, Job, and Solomon are rich and pious. Piety-prosperity equation is ascribed to these people (Davids, 703). This means that wealth in and of itself is not evil. In Jewish tradition, Abraham and Job are wealthy and pious at the same time because of their generosity (The Books of Jub.; Test of Job). In some rabbinic sources, the plight and gravity of the situation of the poor is heightened (Lev. Rab. 34:6 on Lev. 25:25; b. B. Bat. 116a; b. Sanh. 151b.). Exodus Rab 31:12 on Exod. 22:24 states, "There is nothing in the world more pious than poverty-the most terrible of all sufferings. Our teacher said: All sufferings are on one side and poverty is on the other side." P. H. Davids notes that poverty was a real problem in the first century (Davids, 703). The only righteous deed that outranked charity is meditation on the Torah (B. B. Bat. 9a, b; Exod. Rab. 31:1). In fact, it is said, "the poor do more for the wealthy than do the wealthy for the poor" (B. $\check{S} a b b .151 b)$. The theme of caring for the poor in the Law and the Prophets is highlighted in later Judaism. In the life setting of Jesus, poverty is a grave concern and needed to be addressed theologically. Thus, turning a blind eye to the needs of the poor severs oneself from eternal salvation.

\section{Synthesis of the Analysis}

The contextual analysis of the passage has revealed several points in understanding the parable. Poverty is a conscious and real issue in the first century. As part of his mission, Jesus seeks to preach good tidings to the poor (Luke 4:18; 7:22). In Luke, he urges the rich to honor their responsibility for the poor so as to secure them eternal life (18:22), a view supported in Judaism. This responsibility is clearly spelt out in the Law and the Prophets. Ch. 16:14 indicates that the Pharisees are covetous. Being covetous suggests that they have not been honoring their responsibility for the poor as the rich man did in real life. On the other hand, Lazarus would represent the real poor in the life setting of Jesus, whose needs have not been attended to (Hultgren, 115).

Poverty and piety are equated in Luke. Lazarus goes to the bosom of Abraham at death. In Judaism, to be in Abraham's bosom is to have close intimacy with Abraham in Paradise. In the NT in particular, this closeness happens only at the eschatological banquet. In other words, believers' face-to-face encounter with Abraham takes place at the eschaton not immediately after death. The corresponding reality of Abraham's bosom in Luke appears to be the eschatological period when the righteous will be rewarded. Reward for the righteous at the eschaton is a Lucan as well as NT theme. If human being consists of the body-soul equation, then Lazarus' body and soul should have suffered equally while alive. If this consideration is correct, then the body-soul 
equation should be at the bosom of Abraham, not only the soul. The bodily emotions and activities visualized in the parable may be an echo of a familiar religious thought world in Judaism where the righteous dead are usually thought to be in Abraham's bosom or pleasant place. In the final analysis, the poor in Luke will have a close intimacy with Abraham in eschatological Paradise.

If the rich care for the poor, they will be repaid at the resurrection of the just (Luke 14:13-14). The logic of Jesus in 14:13-14 may be that if the rich do not care for the poor, they will suffer punishment at the eschaton. However, because of his neglect of the poor, the rich man in the parable suffers torment in the afterlife (16:22b-23). This scenario finds support in a dominant view of the punishment of the wicked in Hades in Judaism and its surroundings. It appears that Jesus lives in this socio-religious milieu ( $D D A B C$, Vol. 5, 830-1; Hultgren, 111). Arland Hulgren comments that while reflecting the common folktale, the parable is a "creation in its own right" (Hultgren, 111). Jesus meets his audience on their own grounds. Walter Liefeld observes right, "the Pharisees professed belief in a future life and in future judgment. However, they did not live in conformity with that belief but rather in the pursuit of wealth" (Liefeld, 991). It is true that Jesus does not misrepresent facts in parables. His "hearers get a glimpse of the final reversal, in which 'the hungry now... will be filled,' and those "who are filled now... will be hungry"' (6:21, 25; Black, 283). Again in this parable, the rich man suffers torment in Hades, a characteristic of the body-soul equation in either this life or eschatological judgment. When the risen Jesus appears to the disciples, they think that he is a spirit (24:36-37). In response, he says that spirit does not have flesh and bones (v. 39). However, in this parable, the rich man is visualized bodily. He has eyes to see Lazarus, tongue to taste a drop of water, and feeling of torment. If the body-soul equation of the rich man disobeyed on earth, why should the soul (spirit) alone suffer? At least, the body-soul equation of the wicked will be tormented in the eschatological punishment (Rev. 19:20; 20:10-15). So why should only the soul experience an intermediate suffering in this parabolic story (Plummer, 393)? In sum, the rich in Hades may have its corresponding reality in the eschatological punishment of the wicked.

To his immediate audience most excellent Theophilus (Luke 1:3), the parable of the rich and Lazarus is response-evoking. The message of the parable is to strike religious cord with the covetous Pharisees and is response-evoking. Since the care for the poor pervades Luke, it may have been intended also to call for moral response in Theophilus. Considering his title (Cf. Acts 24:2; 26:25) and as some have suggested, he is a person of rank (Carson, Moo, and Morris, 117; O'Toole 2008, Vol. 6, 511-2). This also suggests that he is a person of substance. As the purpose of the "letter" or Gospel of Luke states, Theophilus is to "know the certainty of the truth concerning the things of which you have been informed" (Luke 1:4). Knowing that Jesus teaches and cares for the poor, Theophilus may also be moved to do the same because doing so will secure him a place in the bosom of Abraham.

\section{Conclusion}

It is difficult to resist the following conclusion. First, the theme of wealth and poverty/reverse of fortunes in Luke 16:19-31 appear Lucan and pre-resurrection tradition. It has also been observed that linguistically the passage seems Lucan. Third, the story can be considered as a parable due to certain literary features that it has. Fourth, it has been argued that a quasi-allegorical method may be appropriately used to understand the parable in its present form, specifically the afterlife part. This means that the events and people in the unseen world in this parable may represent/correspond to the real event and class of people in the eschatological judgment. In this case, the rich may represent the covetous Pharisees while Lazarus stands for the physically poor in Jesus' 
time. The bosom of Abraham may point to paradise/heaven where the beneficiaries can welcome the benefactor whereas the Hades may be punishment for the wicked. It has been maintained that since both the body and soul either enjoyed or suffered on earth, reward or punishment should be received by both because they share the same end/fate at the eschaton. The bodily visualization of the disembodied soul/spirit in afterlife may have been employed to have a graphic impact on the minds of the Pharisees as they relate to its corresponding realities. Jesus may have used folktale, in his own way, to teach a lesson that was to have a lasting impression on his immediate addressees.

\section{Works Cited}

Aune, David. Revelation 6-16. Word Biblical Commentary, Vol. 52B. Nashville: Nelson, 1998.

Bar, James. The Garden of Eden and the Hope of Immortality. London: SCM, 1992.

Bauckham, Richard. "The Rich Man and Lazarus: The Parables and the Parallels.” New Testament Studies 37.45 (1991).

---. The Fate of the Dead: Studies on the Jewish and Christian Apocalypse. Leiden: Brill, 1998.

Bauer, Walter. A Greek-English Lexicon of the New Testament and Other Early Christian Literature (BAGD). 2nd ed. Trans. William Arndt and Wilbur Gingrich. Chicago: University of Chicago Press, S.v. "kolpos", 1979.

Berchie, Daniel. Romans 11:11: Israel's Transgression and the Gentiles'Salvation. Saarbrücken: VDM Verlag Dr. Müller, 2010.

Black, Mark . NIV Commentary: Luke, College Press Commentary. Missouri: College Press, 1996.

Blomberg, Craig. Interpreting the Parables. Leicester: Apollos, 1990.

Borland, James. "Gospel of Luke." Liberty Bible Commentary on the New Testament. Eds. Edward Hindson and Woodrow Kroll. Nashville: Thomas Nelson, 1978. n. pag.

Brown, Francis, Samuel Rolles Driver, and Charles Briggs. A Hebrew and English Lexicon of the Old Testament with an Appendix Containing the Biblical Aramaic (BDB). Based on the Lexicon of William Gesenius. Oxford: Clarendon, S.v. " $e l$ äzār" 1952.

Brown, Raymond Edward. The Gospel According to John. Anchor Bible. Garden City: Doubleday, 1966.

Bultmann, Rudulf. The History of the Synoptic Tradition. New York: Harper \& Row, 1963.

Byargeon, Rick. "Listening to the Lyrics: Interpreting Old Testament Wisdom Literature and Poetry." Biblical Hermeneutics: A Comprehensive Introduction to Interpreting Scripture. 2nd ed. Eds. Bruce Corley, Steve Lemke, and Grant Lovejoy. Nashville: Broadman, 2002. 280-300.

Cairus, Aecio. “The Rich and Lazarus: An Apocryphal Interpolation?” Journal of Asia Adventist Seminary 9.1.36 (2006).

Carson, Donald Arthur, Douglas Moo, and Leon Morris. An Introduction to the New Testament. Grand Rapids: Zondervan, 1992.

Davids, Peter. "Rich and Poor." Dictionary of Jesus and the Gospels. Eds. Joel Green and Scot Mcknight. Downers Grove: InterVaristy, 1992. 701-10.

Drury, John. The Parables in the Gospel: History and Allegory. New York: Crossroad, 1985.

Ellis, Earle. "New Testament's Use of the Old Testament." Biblical Hermeneutics: A Comprehensive Introduction to Interpreting Scripture. 2nd ed. Eds. Bruce Corley, Steve Lemke, and Grant Lovejoy. Nashville: Broadman, 2002. 72-89.

Erickson, Millard. Christian Theology. 2nd ed. Grand Rapids: Baker. Evans, Craig A, 1990.

---. Luke, International Biblical Commentary. Peabody: Hendrickson, 1998.

Francis, Nichol. “A Certain Rich Man (Luke 16:19)." The Seventh-day Adventist Bible Commentary (SDABC), Vol. 5. Washington: Review \& Herald, 1976-1980. 830-2.

Ferguson, Everett. Backgrounds of Early Christianity. 3rd ed. Grand Rapids: Eerdmans, 2003.

Fitzmyer, Joseph. The Gospel According Luke X-XXIV: A New Translation with Introduction and Commentary. New York: Doubleday, 1985.

Geldenhugs, Norval. Commentary on the Gospel of Luke: The English Text with Introduction, Exposition, and Notes. Grand Rapids: Eerdmans, 1983.

Grudem, Wayne. Systematic Theology: An Introduction to Biblical Doctrine. Nottingham: Inter-Varsity, 1994.

Hock, Ronald. "Lazarus and Micyllus: Greco-Roman Backgrounds to Luke 16:19-31." Journal of Biblical Literature 106.456 (1987).

---. “Lazarus and Dives.” The Anchor Bible Dictionary, Vol. 4. Ed. David Noel Freedman. New York: Doubleday, 1992. 
Hultgren, Arland. The Parables of Jesus: A Commentary. Grand Rapids: Eerdmans, 2000.

Jeremias, Joachim. "Paradeisos." Theological Dictionary of the New Testament (TDNT), Vol. 5. Eds. Gerhard Kittel and Gerhard Friedrich. Trans. Geoffrey Bromiley. Grand Rapids: Eerdmans, 5: 769. 1964-1976.

---. The Parables of Jesus. London: SCM, 1972.

Jülicher, Adolf. Die Gleichnisreden Jesu, Vol. 2. Tübingen: Mohr (Paul Siebeck), 1910.

Kendall, Robert Tillman. The Complete Guide to the Parables: Understanding and Applying the Stories of Jesus. Grand Rapids: Chosen Books, 2004.

Liefeld, Walter. "Luke." The Expositor's Bible Commentary with the New International Version of the Holy Bible. Ed. Frank Gaebelein. Grand Rapids: Zondervan, 1984. 797-1059.

Marshall, Howard. The Gospel of Luke: A Commentary on the Greek Text. New International Greek Text Commentary. Grand Rapids: Eerdmans, 1978.

Morris, Leon. The Gospel According to St. Luke: An Introduction and Commentary. Leicester: Inter-Varsity, 1986.

Nolland, John. Luke 9:21-18:34. Word Biblical Commentary. Dallas: Word, 1993.

Oesterley, William Oscar Emil. The Gospel Parables in the Light of their Jewish Background. New York: Macmillan, 1936.

O’Toole, Robert. "Theophilus.” The Anchor Bible Dictionary, Vol. 6. New York: Yale University Press, 2008.

Plummer, Alfred. International Critical Commentary: A Critical and Exegetical Commentary on the Gospel of Saint Luke. 5th ed. Edinburgh: T. \& T. Clark, 1977.

Reiling, J. and J. L. Swellengrebel. A Translator's Handbook on the Gospel of Luke. Leiden: United Bible Society, 1971.

Richards, Lawrence. New International Encyclopedia of Bible Words Based on the NIV and the NASB. Grand Rapids: Zondervan, 1991.

Sloan, Robert and Carey Newman. "Ancient Jewish Hermeneutics." Biblical Hermeneutics: A Comprehensive Introduction to Interpreting Scripture. 2nd ed. Eds. Bruce Corley, Steve Lemke, and Grant Lovejoy. Nashville: Broadman, 2002. 56-71.

Speiser, Ephraim Avigdor. “Akkadian Myths, Epics.” ANET. 3rd ed. Ed. James Pritchard. Princeton: Princeton University Press, 1969. n. pag.

Stefanovic, Ranko. Revelation of Jesus Christ: Commentary on the Book of Revelation. Berrien Springs: Andrews University Press, 2002.

Stein, Robert. Luke, New American Commentary, Vol. 24. Nashville: Broadman, 1992.

Tolar, Wiiliam. "The Grammatical-Historical Method." Biblical Hermeneutics: A Comprehensive Introduction to Interpreting Scripture. 2nd ed. Eds. Bruce Corley, Steve Lemke, and Grant Lovejoy. Nashville: Broadman, 2002. 21-38.

Wallace, Daniel. Greek Grammar Beyond the Basics: An Exegetical Syntax of the New Testament. Grand Rapids: Zondervan, 1996.

Warren, William. "Interpreting New Testament Narrative: The Gospels and Acts." Biblical Hermeneutics: A Comprehensive Introduction to Interpreting Scripture. 2nd ed. Eds. Bruce Corley, Steve Lemke, and Grant Lovejoy. Nashville: Broadman, 2002. 316-30.

Wilson, John. "Egyptian Myths, Tales, and Mortuary Texts." Ancient Near Eastern Texts Relating to the Old Testament (ANET). 3rd ed. Ed. James Pritchard. Princeton: Princeton University Press, 1969. n. pag.

Womack, Morris. Learning to Live from the Parables: Timeless Stories Jesus Told about Life. Joplin: College, 1995.

Wright, Stephen. Tales Jesus Told: An Introduction to the Narrative Parables of Jesus. Carlisle: Paternoster, 2002. 